\title{
PELAKSANAAN ASUHAN KEPERAWATAN YANG BERMUTU DI RUMAH SAKIT
}

\author{
Elisa Claudia Simanjuntak / 181101114 \\ elclaudia02@gmail.com
}

\begin{abstract}
ABSTRAK
Latar Belakang : Di rumah sakit, perawat bertugas memberikan asuhan keperawatan yang bermutu. Untuk dapat melakukan hal itu, perawat harus bertindak sesuai dengan standar dan mengikuti kaidah-kaidah yang berlaku di rumah sakit.

Tujuan : Tujuan penulisan kajian ini adalah untuk mengetahui gambaran pelaksanaan asuhan keperawatan yang bermutu di rumah sakit.

Metode : Metode yang digunakan dalam kajian ini adalah literature review, yaitu dengan cara menganalisis, mengeksplorasi serta mengkaji bebas jurnal dan buku teks yang membahas tentang pelaksanaan asuhan keperawatan di rumah sakit.

Hasil : Hasil kajian menunjukkan bahwa pelaksanaan asuhan keperawatan yang bermutu dilakukan berdasarkan kaidah atau wewenang pelayanan kesehatan.

Pembahasan : Asuhan keperawatan adalah proses atau rangkaian kegiatan pada praktik keperawatan yang diberikan secara langsung kepada pasien di berbagai tatanan pelayanan kesehatan. Asuhan keperawatan dilakukan untuk mencapai tujuan yang diharapkan, yaitu menyembuhkan penyakit maupun meningkatkan taraf kesehatan pasien.

Kata Kunci : Asuhan Keperawatan, Bermutu, Rumah Sakit.
\end{abstract}




\section{Latar Belakang}

Rumah sakit merupakan sarana pelayanan kesehatan yang dibuat untuk memudahkan atau melakukan tindakan bagi pasien yang memiliki masalah kesehatan maupun pasien yang ingin meningkatkan taraf kesehatannya. Di rumah sakit, perawat bertugas memberikan asuhan keperawatan yang bermutu. Untuk dapat melakukan hal itu, perawat harus bertindak sesuai dengan standar dan mengikuti kaidahkaidah yang berlaku di rumah sakit.

Asuhan keperawatan yang bermutu dilakukan untuk menyelesaikan masalah pasien dan memenuhi kebutuhannya. Sebelum melakukannya ada prinsip atau pedoman yang harus diperhatikan agar asuhan keperawatan dapat berjalan dengan baik.

\section{Tujuan}

Pengkajian ini dilakukan untuk mengetahui gambaran pelaksanaan asuhan keperawatan yang bermutu di rumah sakit.

\section{Metode}

Metode yang digunakan dalam kajian ini adalah literature review, yaitu dengan cara menganalisis, mengeksplorasi serta mengkaji bebas jurnal dan buku teks yang membahas tentang pelaksanaan asuhan keperawatan di rumah sakit. Referensi berupa jurnal dan buku teks yang digunakan adalah sebanyak 14. Jurnal yang digunakan sebagai referensi dalam tulisan ini diterbitkan dalam kurun waktu 10 tahun terakhir.

\section{Hasil}

Pelaksanaan asuhan keperawatan atau implementasi merupakan tahap dimana rencana asuhan keperawatan yang telah disusun, diterapkan kepada pasien sebagai tindakan untuk menyelesaikan masalah pasien. Pelaksanaan asuhan keperawatan yang bermutu dilakukan berdasarkan kaidah atau wewenang pelayanan kesehatan.

\section{Pembahasan}

Asuhan keperawatan adalah proses atau rangkaian kegiatan pada praktik keperawatan yang diberikan secara langsung kepada pasien di berbagai tatanan pelayanan kesehatan (Ali, 2002). Asuhan keperawatan dilaksanakan berdasarkan kaidah-kaidah keperawatan atau kewenangan pelayanan keperawatan melaksanakan 
pengkajian keperawatan kepada individu di sarana kesehatan yang meliputi status bio-psikososial-kultural dan spiritual klien, merumuskan diagnosis keperawatan terkait dengan fenomena tidak terpenuhinya kebutuhan dasar manusia, menyusun rencana untuk tindakan keperawatan sederhana dan kompleks pada individu, kelompok, dan masyarakat di sarana kesehatan, melaksanakan tindakan keperawatan yang telah dilakukan, mendokumentasikan hasil keperawatan yang dilaksanakan (Kusnanto, 2004).

Pelaksanaan asuhan

keperawatan atau implementasi merupakan tahap dalam proses keperawatan dimana rencana akan diterapkan kepada pasien. Implementasi dilakukan untuk mencapai tujuan yang diharapkan, yaitu menyembuhkan penyakit maupun meningkatkan taraf kesehatan pasien. Ada tiga prinsip pedoman dalam melakukan asuhan keperawatan atau implementasi, yaitu:

1. Mempertahankan keamanan klien Keamanan pasien merupakan fokus utama dalam melakukan tindakan atau asuhan keperawatan.

2. Memberikan asuhan yang efektif

Semakin baik pengetahuan dan pengalaman yang dimiliki perawat, maka semakin efektif asuhan yang akan diberikan.

3. Memberikan asuhan seefisien mungkin

Asuhan keperawatan yang efisien berarti perawat mampu menyelesaikan masalah pasien dengan menggunakan waktu sebaik mungkin (Haryanto, 2008).

\section{Penutup}

Dalam tahap implementasi atau pelaksanaan asuhan keperawatan, perawat harus memperhatikan keamanan, efektivitas, dan efisiensi asuhan keperawatan. Hal itu dilakukan agar asuhan keperawatan yang diberikan dapat membantu pasien menyelesaikan masalahnya.

\section{Referensi}

Astar, F. dkk. (2018). Pengaruh Pelayanan Asuhan Keperawatan Terhadap Kepuasan Pasien di Puskesmas Takalala Kabupaten Soppeng. Journal of Management. 1(2): 33-57.

Bumulo, M. I. dkk. (2017). Pengaruh Manajemen Model Asuhan Keperawatan Profesional Tim 
Terhadap Kualitas Pelayanan

Keperawatan di Bangsal Pria RSUD

Datoe Binangkang Kabupaten Bolaang

Mongondow. e-Jurnal Keperawatan.

5(2): 1-6.

Deswani. (2009). Proses Keperawatan

dan Berpikir Kritis. Jakarta: Salemba

Medika.

Haryanto. (2008). Konsep Dasar

Keperawatan dengan Pemetaan Konsep

(Concept Mapping). Jakarta: Salemba Medika.

Hastuti, W. \& Widiyaningsih. (2017).

Aplikasi Concept Mapping Dalam

Pemberian Asuhan Keperawatan di

Stase Maternitas. Jurnal Keperawatan

dan Pemikiran Ilmiah. 3 (3): 19-26.

Lismidar, H. dkk. (1990). Proses

Keperawatan. Jakarta: UI Press.

Maryam, Siti, dkk. (2006). Buku Ajar

Berpikir Kritis dalam Proses

Keperawatan. Jakarta: EGC.

Potter \& Perry. (2005). Buku Ajar Fundamental Keperawatan: Konsep, Proses, dan Praktik Edisi 4. Jakarta: EGC.
Simamora, R.H. (2009). Dokumentasi Proses Keperawatan. Jember: Jember University Press.

Simamora, R.H. (2010). Komunikasi dalam Keperawatan. Jember: Jember University Press.

Simamora, R. H. (2008). Peran Manajer dalam Pembinaan Etika Perawat Pelaksana dalam Peningkatan Kualitas Pelayanan Asuhan Keperawatan. Jurnal IKESMA. 4(2).

Syafrini, R. O. dkk. (2015). Efektivitas Implementasi Asuhan Keperawatan Isolasi Sosial dalam MPKP Jiwa Terhadap Kemampuan Klien. Jurnal NERS. 10(1): 175-182.

Tarwoto \& Wartonah. (2012). Kebutuhan Dasar Manusia dan Proses Keperawatan. Jakarta: Salemba Medika.

Vaughans, Bennita W. (2013). Keperawatan Dasar. Yogyakarta: Rapha Publishing. 